\title{
Use of medicinal plants by black women: ethnography study in a low-income community*
}

\author{
USO DE PLANTAS MEDICINAIS POR MULHERES NEGRAS: ESTUDO ETNOGRÁFICO \\ EM UMA COMUNIDADE DE BAIXA RENDA
}

\author{
USO DE LAS PLANTAS MEDICINALES POR LAS MUJERES NEGRAS: ESTUDIO \\ ETNOGRÁFICO EN UNA COMUNIDAD DE BAJOS INGRESOS
}

\section{Patricia Lima Ferreira Santa Rosa 1, Luiza Akiko Komura Hoga ${ }^{2}$, Mônica Feitosa Santana ${ }^{3}$, Pâmela Adalgisa Lopes Silva ${ }^{4}$}

\begin{abstract}
Objective: To explore beliefs, values and practices related to the use of medicinal plants among low-income black families. Method: The research method was ethnography and the participant observation process was done in a low-income community in the peripheral area of the City of São Paulo. Twenty black women were interviewed. Results: Two cultural subthemes, I do use medicines that I learned to make with my mother and with religious practitioners to care for diseases and Home medicines are to treat problems that are not serious, and the cultural theme $I$ do use home medicines to treat simple diseases because I always have them at my disposal, they are free and I don't need a medical prescription represent beliefs, values, and practices related to the use of medicinal plants among low-income black families. Conclusion: The development of such practices, which can hide ethnic and social vulnerability, reveals the resilience of low-income black women in the process of confronting problems during the healthillness process.
\end{abstract}

\section{DESCRIPTORS}

Plants, medicinal

Blacks

Anthropology, cultural

Women's health

Qualitative research.

\section{RESUMO}

Objetivo: Explorar crenças, valores e práticas relativas ao uso das plantas medicinais entre famílias negras de baixa renda. Método: Pesquisa etnográfica cujo processo de observação participante foi desenvolvido em uma comunidade de baixa renda da periferia da Cidade de São Paulo. Vinte mulheres negras foram entrevistadas. Resultados: Dois subtemas culturais, Uso remédios que aprendi a fazer com minha mãe e com os religiosos para cuidar das doenças e Remédios caseiros servem para resolver problemas que não são graves, e o tema cultural Uso remédio caseiro para resolver doenças simples, pois tenho sempre que preciso, é de graça e não precisa de receita médica representam as crenças, valores e práticas relativos ao uso das plantas medicinais entre famílias negras de baixa renda. Conclusão: $O$ desenvolvimento dessas práticas, que pode estar mascarando vulnerabilidades étnicas e sociais, revela a resiliência das mulheres negras de baixa renda no enfrentamento dos problemas que encontram no processo saúdeenfermidade.

\section{DESCRITORES \\ Plantas medicinais \\ Negros \\ Antropologia cultural \\ Saúde da mulher \\ Pesquisa qualitativa.}

\begin{abstract}
RESUMEN
Objetivo: Explorar las creencias, valores y prácticas sobre el uso de las plantas medicinales entre las familias negras de bajos ingresos. Método: El método de investigación fue la etnografía y el proceso de observación participante fue desarrollado en una comunidad de bajos ingresos en las afueras de la Ciudad de São Paulo. Se entrevistó a veinte mujeres negras. Resultados: Dos subtemas culturales Uso remedios que aprendí a hacer con mi madre y con los religiosos para cuidar de enfermedades y Remedios caseros se utilizan para resolver problemas que no son graves y el tema cultural Uso remedio casero para resolver enfermedades simples porque tengo todo lo que necesito, es gratuito y no necesita una receta médica simbolizam las prácticas de las mujeres.Conclusión: Estas prácticas, que pueden estar enmascarando vulnerabilidades étnicas y sociales, ponen de manifiesto la resiliencia de las mujeres negras de bajos ingresos en el confrontamiento de los problemas del proceso salud-enfermedad.
\end{abstract}

\author{
DESCRIPTORES \\ Plantas medicinales \\ Negros \\ Antropología cultural \\ Salud de la mujer \\ Investigación cualitativa.
}

* Extracted from the dissertation "Black women, the care of the health and the barriers to seek health care: an ethnographic study in a low income community", Graduate program in nursing, School of Nursing, University of São Paulo, 2013. ${ }^{1}$ Student of the Doctorate program, Graduate program in nursing, School of Nursing, University of São Paulo, São Paulo, state of São Paulo, Brazil. ${ }^{2}$ Associate Professor, Maternal-Child and Psychiatric Nursing Department, School of Nursing, University of São Paulo, São Paulo, state of São Paulo, Brazil. ${ }^{3}$ Student of the Master's program, Department of Social and Work Psychology, Institute of Psychology, University of São Paulo, São Paulo, state of São Paulo, Brazil. ${ }^{4}$ Student of the Undergraduate program in nursing, University of São Paulo, São Paulo, state of São Paulo, Brazil. 


\section{INTRODUCTION}

The adoption of medicinal plants with therapeutic objectives assume specific meanings among African-American families, which may also be influenced by religious rituals performed with mystical and curative aims ${ }^{(1-2)}$. This situation is no different among Brazilian black families; although the members of these families have no knowledge of the religious aspects of the use of plants, they are widely used and represents cultural practices based on knowledge passed down from one generation to the next ${ }^{(3)}$.

The use of medicinal plants with therapeutic objectives is a practice that is very common among the Brazilian population. The Brazilian Health Surveillance Agency began regulating this practice in $2013^{(4)}$. This agency defined medicinal plants as plant species, cultivated or not, used with therapeutic objectives ${ }^{(4)}$ and created specific legislation regarding this subject. Therefore, the processes of preparation, dispensing and storage of herbal medicines are regulated in the sphere of the Brazilian Unified Health System (SUS, as per its acronym in Portuguese) $)^{(4)}$.

Many researchers have studied the use of medicinal plants, especially in the community context, where beliefs and values related to health care, including the use of herbal medicines, are deeply ingrained. They are practices based on knowledge passed down from one generation to the next, in the family and social spheres, and remain limited to the members of the cultural group where they are carried out ${ }^{(5-6)}$.

It is important to note that the terms black, black population and African-Descendant are used with similar meaning in this study and they mean that the individuals or groups of individuals are part of the Brazilian population segment belonging to the black or African-Descendant population. These terms are used in studies that focus on the issues of blackness as an ethnic and racial analysis category. When we use these terms we also refer to the portion of the Brazilian population who self-declare as black or mixed, according to the criteria for race and color made available by the Brazilian Institute of Geography and Statistics (IBGE, as per its acronym in Portuguese). This terminologies is commonly used because of the similarities that exists between social indicators present in the two populations in epidemiological studies ${ }^{(7)}$. Based on this fact, the same line of thinking was adopted to refer to the women who collaborated in this study.

When planning and developing health care for the black community, especially taking into account the particular aspects related to the use of medicinal plants with therapeutic objectives, knowledge of such habits by healthcare professionals has special importance. When looking into deepening this knowledge, healthcare professionals cannot ignore the possibility that such practices of care and healing are derived from the socioeconomic problems that affect this segment of the population. In this scenario, there is also a need to focus on the situa- tions of vulnerability to which these individuals are subjected regarding the inadequate use of medicinal plants.

A review of the scientific literature shows that there is a gap in scientific knowledge related to the practices of care and healing carried out through the use of medicinal plants among Brazilian black women. Aiming to help fill this gap, this study was developed to obtain the answer to the following question: What are the beliefs and values that permeate the daily practices of low-income black women related to the use of medicinal plants in the health-illness process?

This study had the objective of exploring the beliefs, values and practices of Brazilian low-income black women related to the use of medicinal plants when caring for their own health and the health of other family members.

\section{METHOD}

It was a study with a qualitative approach, developed through the ethnographic method, suitable for exploring beliefs, values and practices performed in specific sociocultural contexts ${ }^{(9)}$. This method demands the employment of the participant observation (PO) process, which starts with mostly observation, which is gradually replaced by increasingly active participation in the daily practices of the researched culture ${ }^{(8)}$.

The study was conducted in a low-income neighborhood located in the suburbs of the city of São Paulo. This neighborhood was chosen because $40 \%$ of its population is black ${ }^{(10)}$, in addition to the high level of social vulnerability $^{(11)}$ to which its residents are subjected. Racial discrimination is being increasingly recognized as a determinant of ethnic and racial inequalities in health care, with clear growth and strong association between racial discrimination and effects on the health of adults, young people and children ${ }^{(12-13)}$. The focus of this study was the women because they generally take upon themselves the responsibilities related to practices of care and healing of the health-illness process in the family and social context ${ }^{(14)}$.

When carrying out the PO process, data from the cultural setting were noted in a field diary prepared for that objective ${ }^{(8-9)}$. Insertion in the cultural setting and approaching informants for the study were made in an easier way by the fact that one of the researchers lived in the neighborhood for 17 years. Taking into account the obstacles that are intrinsic to the study of a cultural setting by a researcher who once was part of it, special attention was dedicated to sustaining an attitude of novelty regarding the culture's daily practices ${ }^{(15)}$. On the other hand, this prior familiarity with the researched culture made it possible to carry out the observation phase in a short period. This made it possible to advance to the next phase, active participation in the culture's daily practices, and begin the ethnographic interviews with the women who live in the neighborhood, who became informants in the study.
Use of medicinal plants by black women: ethnography study in a low-income community Santa Rosa PLF, Hoga LAK, Santana MF, Silva PAL 
Informant is the denomination given to participants in ethnographic studies. Culture natives may become general informants if they are interested in the theme and can easily express beliefs, values and daily practices related to the researched theme. Key informants are selected among them. Key informants have deep knowledge, high familiarity and experience regarding the theme being studied(8).

Inclusion criteria in the research were visible phenotypic characteristics of African descent, including dark skin color independent of tone and gradation, and its association or lack there of with hair texture and nose shape. However, self-declaration as a person of black was essential.

The concept of race adopted in this research has an analytical meaning, claimed by sociology, which refers to discourses regarding the origins of a group. Such discourses use terms that refer to the transmission of physiognomic traits, or moral, intellectual, blood and psychological qualities. In this study, the concept of race is understood as a social construct that, in the sociology field or in social sciences, studies social identities from the cultural perspective ${ }^{(16)}$.

The first informant was a person who belonged to the family network of one of the researchers. Subsequent informants were included through the snowball technique, where the interviewee refers to other potential informants who are part of the same social network. It is an effective strategy for adding new informants in ethnographic studies. It is also widely used in other types of qualitative studies ${ }^{(17)}$. During the process of adding new informants, special attention was given to the inclusion of women of different ages, education levels, religions, and formal or informal paid work.

Ethnographic questions of a descriptive and exploratory character were used at the beginning of the interviews to facilitate the expression of beliefs, values and daily practices of the cultural group. The following questions were presented: 1) Tell me about healthcare practices present in your daily life related to yourself and the people who live with you. 2) In the event of disease, what did you learn about care and healing practices and use of medicinal plants for this objective? 3) What do you take into account when caring for a disease at home, or do you think it is better to look for help outside your home? 4) What resources do you seek in that case? 5) Tell me if you have ever felt any difference in treatment from health professionals because you are black.

Before beginning the interviews, we obtained data related to sociodemographic characteristics such as: age, religion, marital status, years of education, work, income, leisure, people who lived with the subjects and how long they have lived in the neighborhood.

Twenty-two women were invited to becoming informants in the study. Two of them refused, claiming to be intimidated by the recorder. Therefore, 20 women were interviewed, three key informants and 17 general informants. The parameters for interviewing this many women were continuous repetition of the answers content, starting in the 15th interview, and reaching theoretical saturation, understood as the possibility of describing the researched theme with comprehensiveness and, above all, depth $^{(8,18)}$. Having 20 informants made it possible for us to also reach the needed diversity of age, religion, education level and income.

The face-to-face interviews, carried out between August and September 2013, were scheduled in person or by telephone and carried out in the informants' homes or workplaces. The informants' preferences for dates, times and places were respected.

All interviews lasted from 40 minutes to 1 hour and 10 minutes, and were recorded on audio in their entirety, transcribed fully and, afterwards, the questions were deleted. Analysis of the interviews was performed using an inductive and interpretative process, so that it was possible to build cultural themes and sub-themes, which symbolize the care and healing practices carried out with medicinal plants. Small excerpts were extracted from the original accounts to exemplify the main content of the sub-themes and the cultural theme. Although the informants did not use exactly the same words to describe their experiences, those whose accounts were similar regarding the researched topic were identified with sequence numbers $(11,12,13 \ldots)$, according to the sequence of interviews. This strategy, important in defining the components of the sub-themes and cultural theme, represents one of the main rigor aspects in the performance of ethnographic research ${ }^{(8)}$.

Another rigor aspect, essential for ethnographic research, is the validation of results with the informants. Therefore, the titles of the sub-themes and the cultural theme and the main contents were presented, schematically, to the key informants. All of them reaffirmed the veracity of the facts symbolized in the presented results.

The research project was submitted to a Research Ethics Committee, accredited by the Brazilian National Council for Ethics on Research, and its development was approved under number 403,369.

\section{RESULTS}

\section{The characteristics of the sociocultural setting}

The neighborhood population of 17,314 registered by the Family Health Program is distributed among 4,772 families. This number may be underestimated because many inhabitants are not found at their houses by the community health agents, who are responsible for registering neighborhood inhabitants. The scarcity of health resources was noted, since the Family Health Program establishes a proportion of one Basic Health Center for every 12,000 people. 
The neighborhood is located about $30 \mathrm{~km}$ from the center of the city of São Paulo, so living there means being forced to travel long distances for access to resources that are considered basic, such as mail services, gas stations, notary offices, banks, hospitals, and emergency centers, among others. The neighborhood is in an area of wellsprings. As a consequence, many social resources are not present in the neighborhood because of the obstacles created by environmental laws. Problems related to transportation are also noticeable, because it is difficult and dangerous as result of the serpentine roads that border the neighborhood, in addition to the serious risk of falling in the reservoir that surrounds the area.

Regarding the origins of the informants, they came from the states of Bahia (10), Minas Gerais (5), Pernambuco (3), and one was from the state of São Paulo. The reason for migration as teenagers or young adults was the desire to look for better living conditions in São Paulo. Therefore, acquiring their own houses represented a victory against the rampant real estate speculation that takes place in the capital of the state of São Paulo; owning a home meant the possibility of breaking free from paying rent and getting out of the slums, where many people lived before coming to the neighborhood. The informants who had arrived first in the neighborhood reported that, around fifteen years ago, the location had characteristics very close to those of the countryside. Since that time, it has gone through an intense urbanization process, but without the right urban planning. Consequently, the population also suffers from a scarcity of leisure and urban mobility services.

Chart 1 presents the sociodemographic characteristics of key and general informants.

Chart 1 - Sociodemographic characteristics of the informants.

\begin{tabular}{|c|c|c|c|c|c|c|c|c|c|}
\hline $\begin{array}{l}\text { Informants } \\
\text { Key (K) or } \\
\text { General (G) }\end{array}$ & $\begin{array}{c}\text { Age } \\
\text { (years) }\end{array}$ & Religion & $\begin{array}{l}\text { Marital } \\
\text { Status* }\end{array}$ & $\begin{array}{l}\text { Educa- } \\
\text { tion } \\
\text { (years) }\end{array}$ & Occupation & $\begin{array}{c}\text { Family } \\
\text { income (min. } \\
\text { wage)** }\end{array}$ & Leisure & $\begin{array}{l}\text { People living } \\
\text { in the same } \\
\text { dwelling*** }\end{array}$ & $\begin{array}{c}\text { Time living in the } \\
\text { neighborhood } \\
\text { (years) }\end{array}$ \\
\hline I1 - K & 58 & Catholic & M & 3 & Housework & 2.2 & Watching TV & $\mathrm{H}$ and $\mathrm{C}$ & 22 \\
\hline $\mathrm{I} 2-\mathrm{G}$ & 32 & Catholic & $\mathrm{S}$ & 13 & Unemployed & 2.2 & Visiting relatives & $\mathrm{P}$ and $\mathrm{O}$ & 22 \\
\hline I3 - G & 27 & Catholic & SR & 11 & Unemployed & 2.2 & $\begin{array}{l}\text { Visiting relatives; } \\
\text { reading; parks }\end{array}$ & $\mathrm{H}$ and $\mathrm{C}$ & 11 \\
\hline I4 - G & 28 & $\begin{array}{l}\text { Candomblé } \\
\text { practitioner }\end{array}$ & SR & 11 & $\begin{array}{l}\text { Merchant } \\
\text { Hairdresser }\end{array}$ & 14.7 & $\begin{array}{l}\text { Going to the } \\
\text { mall; reading; } \\
\text { listening to music }\end{array}$ & $\mathrm{H}$ & 23 \\
\hline $\mathrm{I} 5-\mathrm{G}$ & 54 & Catholic & M & 4 & $\begin{array}{l}\text { Merchant Bar } \\
\text { and Grocery } \\
\text { Store }\end{array}$ & 5.9 & Watching TV & $\mathrm{H}$ & 16 \\
\hline I6 - G & 32 & Evangelical & M & 9 & $\begin{array}{l}\text { Merchant } \\
\text { Hairdresser }\end{array}$ & No income & - & $\mathrm{H}$ & 15 \\
\hline I7 - K & 46 & Catholic & M & 14 & Pedagogue & 6.6 & $\begin{array}{c}\text { Watching } \\
\text { amateur soccer; } \\
\text { religion; movies; } \\
\text { hiking; house } \\
\text { parties }\end{array}$ & $\mathrm{H}$ and $\mathrm{C}$ & 15 \\
\hline I8 - G & 51 & Catholic & M & 8 & Housework & 5.9 & $\begin{array}{l}\text { Gymnastics; } \\
\text { dancing; } \\
\text { traveling; house } \\
\text { parties }\end{array}$ & $\mathrm{H}$ and $2 \mathrm{C}$ & 15 \\
\hline I9 - G & 30 & Evangelical & SR & 11 & Housework & 2.2 & Religion & $\mathrm{H}$ and $4 \mathrm{C}$ & 23 \\
\hline $\mathrm{I} 10-\mathrm{G}$ & 36 & Evangelical & SR & 11 & $\begin{array}{l}\text { Merchant } \\
\text { Manicurist }\end{array}$ & Not stated & $\begin{array}{l}\text { Walks in the park } \\
\text { or mall }\end{array}$ & $\mathrm{H}$ and $2 \mathrm{C}$ & 15 \\
\hline I11 - G & 64 & Evangelical & M & 8 & Retired & 2.1 & Watching TV & $\mathrm{H}$ & 14 \\
\hline I12 - K & 62 & Evangelical & M & 5 & Housework & Not fixed & $\begin{array}{c}\text { Watching TV; } \\
\text { reading }\end{array}$ & $\mathrm{H}$ and $\mathrm{C}$ & 15 \\
\hline I13 - G & 50 & Catholic & M & 8 & Housework & 2.9 & $\begin{array}{c}\text { Going to the } \\
\text { movies; watching } \\
\text { TV }\end{array}$ & $\mathrm{H} ; \mathrm{P} ; \mathrm{C}$ and $\mathrm{O}$ & 13 \\
\hline $\mathrm{I} 14-\mathrm{G}$ & 32 & Catholic & M & 7 & Housework & 1.3 & $\begin{array}{c}\text { Watching } \\
\text { amateur soccer; } \\
\text { visiting relatives; } \\
\text { watching TV }\end{array}$ & $\mathrm{H}$ and $3 \mathrm{C}$ & 6 \\
\hline $\mathrm{I} 15-\mathrm{G}$ & 28 & $\begin{array}{l}\text { Umbanda } \\
\text { practitioner }\end{array}$ & M & 11 & Housework & 1.3 & $\begin{array}{c}\text { Watching } \\
\text { amateur soccer; } \\
\text { watching TV }\end{array}$ & $\mathrm{H} ; \mathrm{O}$ and $\mathrm{C}$ & 1 \\
\hline $\mathrm{I} 16-\mathrm{G}$ & 56 & No religion & M & 3 & Housemaid & 4.4 & $\begin{array}{c}\text { Watching TV; } \\
\text { listening to } \\
\text { music; visiting } \\
\text { friends/neighbors }\end{array}$ & $\mathrm{H}$ & 17 \\
\hline
\end{tabular}


Continuation...

\begin{tabular}{|c|c|c|c|c|c|c|c|c|c|}
\hline $\begin{array}{l}\text { Informants } \\
\text { Key (K) or } \\
\text { General (G) }\end{array}$ & $\begin{array}{c}\text { Age } \\
\text { (years) }\end{array}$ & Religion & $\begin{array}{l}\text { Marital } \\
\text { Status* }\end{array}$ & $\begin{array}{l}\text { Educa- } \\
\text { tion } \\
\text { (years) }\end{array}$ & Occupation & $\begin{array}{c}\text { Family } \\
\text { income (min. } \\
\text { wage) })^{* *}\end{array}$ & Leisure & $\begin{array}{l}\text { People living } \\
\text { in the same } \\
\text { dwelling*** }\end{array}$ & $\begin{array}{c}\text { Time living in the } \\
\text { neighborhood } \\
\text { (years) }\end{array}$ \\
\hline $\mathrm{I} 17-\mathrm{G}$ & 23 & Catholic & $\mathrm{S}$ & 11 & Unemployed & 3.7 & $\begin{array}{c}\text { Visiting relatives, } \\
\text { going to night } \\
\text { clubs, watching } \\
\text { TV }\end{array}$ & $\mathrm{P}, \mathrm{e} \mathrm{O}$ & 5 \\
\hline $\mathrm{I} 18-\mathrm{G}$ & 43 & Catholic & M & 11 & Housework & 1.8 & Visiting relatives & $\mathrm{H}$ and $2 \mathrm{C}$ & 4 \\
\hline $\mathrm{I} 19-\mathrm{G}$ & 26 & $\begin{array}{l}\text { Candomblé } \\
\text { practitioner }\end{array}$ & SR & 8 & Housework & 1.7 & Watching TV & $2 \mathrm{~F}$ & 11 \\
\hline $\mathrm{I} 20-\mathrm{G}$ & 47 & Evangelical & M & 11 & $\begin{array}{l}\text { Nursing } \\
\text { Technician }\end{array}$ & 4.4 & $\begin{array}{l}\text { Club; visiting } \\
\text { relatives; eating } \\
\text { at restaurants }\end{array}$ & $2 \mathrm{C}$ and $\mathrm{H}$ & 17 \\
\hline
\end{tabular}

* Single (S); Married (M); Stable relationship (SR)

** Current value of minimum wage at the time of interview: R\$ 678.00

*** Parents $(\mathrm{P})$; Husband $(\mathrm{H})$; Children $(\mathrm{C})$; Others $(\mathrm{O})$

\section{Sub-themes and the cultural theme}

\section{Cultural sub-theme 1: I do use medicines that I learned to make with my mother and with religious practitioners to care for diseases}

The use of medicinal plants in home recipes to treat their own diseases and the diseases of the other members of the family was almost unanimous among the women. They see such resources as a way to overcome a health situation likely to be solved through their own means.

(...) we do a lot with home tea $(11,12,13,14,15,17,18,19$, I10, I11, I12, I13, I14, I16, I17, I18, I20).

It was noted that there is a difference among generations regarding the use of such resources. Older women resorted more habitually to care and cure resources learned in the domestic and family context, including the preparation and use of medicinal plants. Younger women, on the other hand, were more prone to search for care and healing resources at health institutions in case of disease.

There is a big difference in how I treat my health and how my mother would, because she is from another generation. Younger people get sick and quickly go looking for a doctor and the elders say: No, l'll be much better tomorrow. My mother says: I'm fine, tomorrow l'll be better and she never goes to the doctor. My mother is a kind of healer (benzedeira). If anyone wants to be blessed, she also blesses them (I17).

Women were categorical when claiming that the use of medicinal plants as a care and healing resource for diseases was a much more common practice some years ago, especially in the states which they were came from, where access to the healthcare system was harder and almost impractical.

(...) In the old days, there was a lot more. Nowadays, not so much. Especially in the state where I used to live (I1, I2, I3, I5 I7, I8, I9, I10, I11, I12, I13, I14, I16, I17, I18, I20).

Knowledge regarding care and cure resources, including the preparation and use of medicinal plants, were passed down from one generation to the next in the family context or through religious leaders, especially those in charge of pastoral healthcare centers and Umbanda temples.

\footnotetext{
I learned about the leaves with my mother and with my grandmother. Back then, my grandmother on my mother's side. There was no such thing as a doctor, we only had home tea. That's because they knew all kinds of leaves $(I 1, \mathrm{I} 2, \mathrm{I}, \mathrm{I}, 11, \mathrm{I12}, \mathrm{I13}, \mathrm{I16}, \mathrm{I20})$.
}

Women whose religions stemmed from African culture, such as Candomble and Umbanda, reported that the use of herbs, leaves and baths made from those elements was a common practice, used daily to try to treat health problems. They reported that some people combine manufactured drugs and herb-based recipes and are concerned about this fact, especially regarding possible problems that might affect their health conditions.

Some people mix with medicines, for example, Citotec $₫$, but that's too strong; after you do that, your uterus is not good anymore. They are under the risk of not getting pregnant anymore or having high-risk pregnancies (14)

\section{Cultural sub-theme 2: Home medicines are to treat problems that are not serious}

Home medicines were used to try to treat health problems considered simple and not severe, such as flu and colds, coughs, abdominal or stomach ache, diarrhea and headaches. Some women even mentioned that such resources were used when trying to treat more severe problems, such as kidney crisis, gallstones and edema.

Things that are treated with teas are flu, stomachaches, headaches... you know, those you can manage with the tea $(I 1,12,13,14,15,17$, I8, I9, I10, I11, I12, I13, I14, I16, I17, $\mathrm{I} 18, \mathrm{I20})$. My husband had a kidney crisis (...) I gave him some shatterstone tea $(17,18)$. There's something called cow hoof and there's another one, monkey cane, which is great. I had an uncle who almost went through surgery to remove bladder stones and then he drank monkey cane and, when it was time, he had expelled the stone $(17,18)$.

In general, home medicines were made from plants cultivated in their own gardens or were provided by neigh- 
bors. The most common ingredients were: mint, pennyroyal, lemon, fennel, garlic, onion, guaco, ginger, honey, vernonia, citron, lemongrass, shatterstone, sponge cucumber, corn silk, avocado seed, pomegranate, chayote peel, manjeroba, cow hoof, monkey cane and white oak. Cultivating herbs in their own gardens was a way to facilitate access to and use of these resources. They could harvest the herbs when they were very fresh or they asked the neighbors, who also had their own crops. A common practice was observed, where vases with a large variety of medicinal plants were cultivated inside the houses or planted in the gardens. Knowledge regarding directions for the use of medicinal plants was similar. They had the habit of using mint teas, pennyroyal, lemon, fennel, garlic and onion to cure flu and colds; guaco, ginger, lemon and honey to cure coughs; vernonia for stomachaches; and lemongrass and lemongrass to soothe nervousness.

In case of flu and colds I make tea with mint, pennyroyal, lemon, garlic and onion. I boil everything with sugar (I1, $13,14,15,17,18,19,110,111,112$, I13, I16, I17, 120). Mint and pennyroyal tea is good for colds, especially for children. Lemongrass is also good for colds if the child has a congested chest. Lemongrass tea is great! (I1). Pineapple syrup is perfect, it has a lot of vitamin $\mathrm{C}$, cuts the flu at once $(I 10$, I11, I14). For coughs I make tea with guaco, ginger, lemon and garlic (15).

\section{Cultural theme: I do use home medicines to treat simple diseases because I always have them at my disposal, they are free and I don't need a medical prescription.}

Knowledge regarding the preparation and use of home medicines was acquired from their own ancestors and their social environment, especially religious leaders. Therefore, it is a practice that is learned from and had its roots in family customs. Although it is a habit that is becoming increasingly scarce.Women continue using this resource to treat health problems considered relatively simple. Because it is a habit rooted in cultural daily life, the cultivation of medicinal plants with therapeutic objectives remains among preserved family practices.

I'm from the Northeast and I remember the stories that my mother used to tell. She used to say that in those times there was no Basic Health Center, that the doctors were all far away; so she cared for us, treated us a lot with home medicines $(I 10,|12| 16$,$) .$

It is clear that for the women, home medicines must be used when health problems are not serious and the home remedies are adequate for treatment. The fact that home medicines are always available or that they may be provided by neighbors is very important for the women. It represents an important route of access to them. Also, home medicines do not have financial costs, and their use does not entail a search for institutionalized health care, whose quality is questioned. Among the women, there was an understanding related to the sequence of use of care and healing resources. First come home medicines and, then institutionalized resources, where health care professionals are found.

I have some plants here in the garden; when I don't, I ask some neighbor $(11,13,14,15,17,18,19,110,111,112,113$, I16, I17, I20). Always first the tea, then the doctor. First we try tea; and then we look for a doctor. That's because it's difficult to get a doctor nowadays; I'm going to give you as an example our own neighborhood's Basic Health Center: if you want to make an appointment you'll only get it for two months from now (I1).

Looking for institutionalized health care outside of the household represents the need to use transportation and pay the costs, in addition to the long distances that must be traversed.

I think that here is too far away from everything (...) this little road is a torture $(I 8, I 20)$. Personally, I don't search for doctors too much, I think the place where we live is a very forgotten place for many reasons (I17). I don't like it here so much, I'm only here because it's mine (own home); if I could choose, l'd be far from here. I think here is far away from everything (...) This little road is very bad (I8)

This set of factors drives the women to use home medicines to treat disease situations they consider simple. In addition, there is the ease represented by free access to them; they are always available, without financial cost, in their own household or the neighborhood. This set of factors, which is strategic when dealing with problems that result from the health-illness process is, above all, valued for the absence of the need to spend money and time, which are essential for accessing healthcare resources available at institutions and to carry on with their own life routine.

\section{DISCUSSION}

The contents of both cultural sub-themes reinforced this ethnographic study's cultural theme: I use home medicines to treat simple diseases because I always have them at my disposal, they are free and I don't need a medical prescription. This theme brings together beliefs, values and practices of black women living in the suburbs of the city of São Paulo related to the use of medicinal plants when caring for their own health and for the health of other members of their families.

Difficulties in searching healthcare facilities due to geographical isolation, which are associated with obstacles of subjective and racial natures ${ }^{(19)}$, in addition to the women's perception that public healthcare facilities offer inadequate care, show a clear overlap of factors that make the group of black women living in the suburbs of São Paulo more vulnerable ${ }^{(20)}$.

In this sense, researchers on the theme of vulnerability articulate concepts of social, environmental and territorial vulnerability to discuss issues related to the health. They consider that social and environmental vulnerability may define 
territories and populations in their relation to environmental risks, intensifying or worsening the health-illness processes ${ }^{(21)}$. We consider which these concepts make great sense in the sphere of collective health care, because they clarify and give due recognition to the territories higher vulnerability. In addition to guide administrators in planning public policies which must be focused on priority territories ${ }^{(21)}$.

In this sense, the use of medicinal plants with therapeutic objectives may be hiding the absence or inadequacy of healthcare facilities, driving the population to use these home medicines for relief and as alternatives to institutionalized health care facilities ${ }^{(22)}$. The non-institutional therapeutic practices used by the women may be related to their perception that the health care they receive is of low quality. This represents a sign of the need to focus more intensely on the theme related to care made available to the black population by the Brazilian Unified Health System. Data from a nationwide epidemiological study revealed that $67 \%$ of the population served by the Brazilian Unified Health System is of blacks. It is a population that has less access to, and exhibits a stronger perception of the inadequacy of, the care performed by health care facilities ${ }^{(23)}$.

The women showed differences in how they acted and thought in relation to everyday and health situations, according to their age group. This finding confirms the results of another study, where it was observed that older women tended to look for therapeutic resources outside of official medicine, especially care and healing resources based on religion ${ }^{(22)}$.

The use of medicinal plants in the preparation of home medicines must be respected as a cultural habit of people who receive nursing care, which is confirmed by results reported in international studies that focus on cultural diversity in health care ${ }^{(1-2)}$. However, it is the duty of health care professionals to remain aware of the possibility that this practice may be hiding potential vulnerability of population segments which have problems accessing the institutionalized health care system, derived from racial, social, environmental and generational discrimination.

\section{REFERENCES}

1. Giger JN. Transcultural nursing: assessment \& interventions. 6th ed. Philadelphia: Elsevier; 2013.

2. White L, Duncan G, Baumle W. Cultural considerations: foundations of basic nursing. São Paulo: Cengage Learning; 2010.

3. Gomes HHS, Dantas IC, Catão MHCV. Plantas medicinais: sua utilização nos terreiros de umbanda e candomblé na zona leste da cidade de Campina Grade-PB. Rev Biol Farmácia. 2008;1(3):110-29.
One study conducted with women living in a low-income community found that they resorted to homegrown medicinal plants to take care of diseases, independent of ethnic origin ${ }^{(14)}$. This information shows the need to verify whether women from other ethnic-social segments of Brazil also resort to medicinal plants for care and healing practices. It is also important to know if the knowledge sources and the women's motivation to carry out such practices are similar or different in relation to what was found in the current study. These results may give concrete indications of the need for sociocultural adjustment when carrying out activities for the promotion and recovery of the health through the use of medicinal plants, already regulated by the Brazilian National Health Surveillance Agency at the level of the Brazilian Unified Health System.

\section{CONCLUSION}

The use of medicinal plants prepared through home recipes with therapeutic objectives is very common in the researched group. It was observed that older women used this care and healing resource more often than younger women. These data show the need to know and consider cultural beliefs, values and practices of care and healing in the process of planning and implementation health and nursing care.

However, we observed the importance of considering the economic, social and environmental vulnerability to which black women living in the suburbs of large cities are subjected. On the other hand, we should take into account the high capacity for resilience showed by low-income black women when dealing with problems in the health-illness process.

New studies focusing on these questions are necessary, because deep knowledge of this area may contribute to the development of socioculturally adequate nursing care. It is important knowledge upon which to base future public policies in the sphere of health care. The inclusion of projects for the promotion and recovery of health through the use of medicinal plants, already regulated by the Brazilian Unified Health System, must be encouraged and included in daily health care practices.

4. Brasil. Ministério da Saúde; Agência Nacional de Vigilância Sanitária. Resolução RDC n. 18, de 3 de abril de 2013. Dispõe sobre as boas práticas de processamento e armazenamento de plantas medicinais, preparação e dispensação de produtos magistrais e oficinais de plantas medicinais e fitoterápicos em farmácias vivas no âmbito do Sistema Único de Saúde (SUS) [Internet]. Brasília; 2013 [citado 2014 mar. 14]. Disponível em: http://bvsms.saude.gov.br/bvs/saudelegis/anvisa/2013/ rdc0018_03_04_2013.html 
5. Di Stasi LC. Plantas medicinais: verdades e mentiras. São Paulo: Ed.UNESP; 2007.

6. Ceolin T, Heck RM, Barbieri RL, Schwartz E, Muniz RM, Pillon $\mathrm{CN}$. Medicinal plants: knowledge transmission in families of ecological farmers in Souther Rio Grande do Sul. Rev Esc Enferm USP [Internet]. 2011 [cited 2014 Apr 17];45(1):47-54. Available from: http://www.scielo.br/pdf/reeusp/v45n1/en_07.pdf

7. Paixão M, Carvano LM. Relatório anual das desigualdades raciais no Brasil; 2007-2008 [Internet]. Rio de Janeiro: Garamond; 2008 [citado 2014 Mar 15]. Disponível em: http://www.laeser. ie.ufrj.br/PT/relatorios pdf/RDR_2007-2008_pt.pdf

8. Leininger MM. Culture care diversity and universality theory and evolution of the ethnonursing method. In: Leininger MM, McFarland MR, editors. Culture care diversity and universality: a worldwide nursing theory. 2nd ed. Sudbury (CA): Jones \& Bartlett; 2006.

9. Geertz C. A interpretação das culturas. Rio de Janeiro: LTC; 2008.

10. Fundação SEADE. Maior população negra do país [Internet]. São Paulo; 2005 [citado 2014 abr. 17]. Disponível em: http:// www.seade.gov.br/produtos/idr/download/populacao.pdf

11. Fundação SEADE. Índice de vulnerabilidade social [Internet]. São Paulo; 2010 [citado 2014 mar. 14]. Disponível em: http:// www.iprsipvs.seade.gov.br/view/pdf/ipvs/principais_resultados.pdf

12. 12. Priest N, Paradies $\mathrm{Y}$, Trenerry B, Truong M, Karlsen S, Kelly $Y$. A systematic review of studies examining the relationship between reported racism and health and wellbeing for children and young people. Soc Sci Med. 2013;95:115-27.

13. Bastos JL, Faerstein E. Conceptual and methodological aspects of relations between discrimination and health in epidemiological studies. Cad Saúde Pública [Internet]. 2012 [cited 2014 Mar 15];28(1):177-83. Available from: http://www.scielosp. org/pdf/csp/v28n1/19.pdf

14. Hoga LAK. Illness care at home or in health institutions: the decision process in a low income community. Rev Lat Am Enfer- magem. 2008;16(1):115-21.

15. Munhall PL. Nursing research: a qualitative perspective. 4 th ed. Sudbury (CA): Jones and Bartlett; 2007.

16. Guimarães ASA. Como trabalhar com "raça" em sociologia. Educ Pesqui [Internet]. 2003 Jun [cited 2014 Mar 15];29(1). Available from:

17. Polit D, Beck C, Hungler B. Fundamentos de pesquisa em enfermagem: métodos, avaliação e utilização. 5a ed. Porto Alegre: Artmed; 2004.

18. Morse J. Qualitative health research: creating a new discipline. Walnut Greek (CA): Left Coast; 2012.

19. Santa Rosa PLF. Mulheres negras, o cuidado com a saúde e as barreiras na busca por assistência: estudo etnográfico em uma comunidade de baixa renda [dissertação]. São Paulo: Escola de Enfermagem, Universidade de São Paulo; 2013.

20. Ayres JRCM, França Junior I, Calazans GJ, Saletti Filho HC. O conceito de vulnerabilidade e as práticas de saúde: novas perspectivas e desafios. In: Czeresnia D, Freitas CM. Promoção da Saúde: conceitos, reflexões e tendências. Rio de Janeiro: FIOCRUZ; 2009. p. 117-39.

21. Porto MFS, Pivetta F. Por uma promoção da saúde emancipatória em territórios vulneráveis. In: Czeresnia D, Freitas CM. Promoção da Saúde: conceitos, reflexões e tendências. Rio de Janeiro: FIOCRUZ; 2009. p. 207-29.

22. Ferreira J, Espírito Santo W. Os percursos da cura: abordagem antropológica sobre os itinerários terapêuticos dos moradores do complexo de favelas de Manguinhos, Rio de Janeiro. Physis Rev Saúde Coletiva. 2012;22(1):179-98.

23. Paixão M, Rossetto I, Montovanele F, Carvano LM. Relatório anual das desigualdades raciais no Brasil; 2009-2010: Constituição Cidadã, seguridade social e seus efeitos sobre as assimetrias de cor ou raça [Internet]. Rio de Janeiro: Garamond; 2011 [citado 2014 mar. 14]. Disponível em: http://www.laeser.ie.ufrj. br/PT/relatorios\%20pdf/Relat\%C3\%B3rio_2009-2010.pdf

\section{Acknowledgments}

To Ph.D. Professors Alessandro de Oliveira dos Santos and Dulce Maria Senna, for their valuable contributions on the qualification and Master's defense boards. To Ph.D. Professor Edna Tomiko Myiake Kato, for her help on issues related to medicinal plants and related legislation.

$\begin{array}{cl}\text { Rev Esc Enferm USP } & \text { Correspondence addressed to: Luiza Akiko Komura Hoga } \\ \mathbf{2 0 1 4} ; \mathbf{4 8}(\text { Esp):45-52 } & \text { Departamento de Enfermagem Materno-Infantil e Psiquiátrica, } \\ \text { www.ee.usp.br/reeusp/ } & \text { Escola de Enfermagem da USP } \\ & \text { Av. Dr. Enéas de Carvalho Aguiar, 419 - Cerqueira Cesar } \\ & \text { CEP 05403-000-São Paulo, SP, Brazil } \\ & \text { E-mail: kikatuca@usp.br }\end{array}$

